\title{
Apoptosis of Bel-7402 human hepatoma cells induced by a ruthenium(II) complex coordinated by cordycepin through the $\mathbf{p 5 3}$ pathway
}

\author{
QUN LU, WENJIE MEI, SHAOHONG LUO and WEIBIN HE \\ Department of Biochemical and Molecular Biology, School of Basic Courses, \\ Guangdong Pharmaceutical University, Guangzhou, Guangdong 510006, P.R. China
}

Received May 5, 2013; Accepted September 18, 2014

DOI: $10.3892 / \mathrm{mmr} .2015 .3297$

\begin{abstract}
A ruthenium(II) complex coordinated by cordycepin, [Cor-Ru(II)], was synthesized for investigation as a potential novel candidate for cancer therapy. The antitumor activity of $\mathrm{Cor}-\mathrm{Ru}(\mathrm{II})$ was investigated by MTT and flow cytometry (FCM) assays. The results showed that Cor-Ru(II) significantly inhibited the proliferation of Bel-7402 human hepatoma cells and delayed cell cycle progression. Subsequent experiments using FCM and western blot analysis indicated that $\mathrm{Cor}-\mathrm{Ru}(\mathrm{II})$ induced cell apoptosis via suppression of bcl-2 expression and stimulation of p53 expression. Cor-Ru(II) was shown to interfere with the synthesis of DNA. This was confirmed by the in vitro binding to DNA in the groove binding mode $\left(\mathrm{K}_{\mathrm{b}}=4.22( \pm 0.2) \times 10^{5} \mathrm{M}^{-1}\right)$. Thus, Cor- $\mathrm{Ru}(\mathrm{II})$ appears to act as an effective antitumor agent in vitro.
\end{abstract}

\section{Introduction}

Recently, there has been an increasing focus on research into ruthenium $(\mathrm{Ru})$ complexes as potential antitumor agents in the field of inorganic drugs, in China and abroad. It is hypothesized that $\mathrm{Ru}$ complexes have a low toxicity and are easily absorbed, as well as possessing the greatest potential antitumor activities of the non-platinum metallic compounds (1-3). Sava et al (4) found that cis and trans $\mathrm{Ru}(\mathrm{II}) \mathrm{Cl}_{2}(\mathrm{DMSO})_{4}$ exhibited antineoplastic activity in a number of metastatic tumors in mice. Keppler et al (5) investigated the antitumor activity of the $\mathrm{Ru}(\mathrm{III})$ complex, $\mathrm{ImH}\left[\right.$ trans $\left.-\mathrm{RuCl}_{4}(\mathrm{Im})_{4}\right]$, also termed ICR, where Im stands for imidazole. They found

Correspondence to: Dr Qun Lu or Dr Wenjie Mei, Department of Biochemical and Molecular Biology, School of Basic Courses, Guangdong Phamaceutical University, 280 Ring Road, Guangzhou, Guangdong 510006, P.R. China

E-mail: qunlucn@163.com

E-mail: wenjiemei@126.com

Key words: ruthenium(II) complex coordinated by cordycepin, Bel-7402 human hepatoma cells, proliferation, inhibition, apoposis that the antitumor activity of this complex was greater than that of cisplatin, whilst its toxicity was lower. The activity of the trans-complex was shown to be higher than that of the cis-complex (5). Furthermore, in 2002 the Ru complex with equivalent quantities of ascorbic acid, glutathione or cysteine prior to administration to mice bearing advanced $\mathrm{MCa}$ mammary carcinoma was more active than NAMI-A alone in vivo (6). In addition, Hotze et al (7) designed and prepared cyclopentadienyl ruthenium, which exhibited a clear inhibitory effect in certain tumor cells. The DNA recognition mechanism of $\mathrm{Ru}$ complexes has also been extensively researched by Zhang et al (8) and Zou et al (9). These groups found that the structure of $\mathrm{Ru}$ complexes, in particular the planar properties of the ligands, the electronic effect of substitute groups, the intramolecular hydrogen bond and the hydrophobicity of ancillary ligands, may influence the interaction mode and the affinity of $\mathrm{Ru}$ complexes to DNA molecules, thus interfering with the DNA double helix structure to varying degrees in order to inhibit the growth of tumor cells.

A number of studies have found that certain compounds have a higher bioactivity when in a complex with metals than they do in their natural state. For example, the anti-inflammatory and anti-allergenic effects of metallic complexes of baicalin are greater than those of baicalin alone $(10,11)$. Chen et al (12) used 3'deoxyadenosine cordycepin as a ligand in order to synthesize a series of molybdenum and copper complexes with increased bioactivity.

3'-deoxyadenosine is also termed cordycepin. It has a molecular formula of $\mathrm{C}_{10} \mathrm{H}_{13} \mathrm{~N}_{5} \mathrm{O}_{3}$, a molecule weight of $251 \mathrm{~g} / \mathrm{mol}$ and a melting point of $230-231^{\circ} \mathrm{C}$. It is soluble in water, hot ethanol and methanol, but insoluble in benzene, diethyl ether and chloroform. Studies have found that 3'-deoxyadenosine influences the synthesis of RNA and DNA, thus preventing cancer cells from dividing (6). Cordycepin exhibited a clear inhibitory effect in Ehrlich ascites carcinoma cells (EAC) and human squamous cell carcinoma, and it can increase the survival time of mice with EAC (13). In 2007, 3'-deoxyadenosine was approved for the treatment of acute lymphoblastic leukemia by the food and drug administration (14). As an inhibitor of adenosine deaminase, studies have found that cordycepin exhibited higher toxicity in leukemia cells that were terminal deoxylnucleotidyl positive $\left(\mathrm{TdT}^{+}\right)$ 
rather than negative (TdT) in vivo (15). Cordycepin has also been shown to regulate certain human endocrine processes and to enhance immune function, as well as to possess antibacterial, anti-inflammatory, antioxidant and anticancer properties (14). The current study used $\mathrm{RuCl}_{3}$ and cordycepin as substrates to synthesize $\left[\mathrm{Ru}(\text { bpy })_{2} \mathrm{C}_{10} \mathrm{H}_{13} \mathrm{~N}_{5} \mathrm{O}_{3}\right] \mathrm{Cl}_{2}$ (Fig. 1). This is a red-brown powder, which is soluble in water, methanol, ethanol, dimethyl sulfoxide (DMSO), diethyl ether and chloroform.

This study aimed to investigate the effect of the ruthenium(II) complex coordinated by cordycepin [Cor-Ru(II)] on DNA synthesis, cell apoptosis and the expression of p53 and bcl-2 in Bel-7402 human hepatoma cells. This was conducted with the objective of contributing to the development of novel chemotherapeutic agents.

\section{Materials and methods}

Reagents. $\left[\mathrm{Ru}(\mathrm{bpy})_{2} \mathrm{C}_{10} \mathrm{H}_{13} \mathrm{~N}_{5} \mathrm{O}_{3}\right] \mathrm{Cl}_{2}$ was produced in the Laboratory of Biochemical and Molecular Biology, School of Basic Courses and the Laboratory of Chemical Pharmacy, College of Pharmacy, Guangdong Phamaceutical University (Guangzhou, China) by a series of chemical reactions linking ruthenium to the pyridyl bond of 3 'deoxyadenosine cordycepin. Propidium iodide (PI), ethidium bromide (EB)-DNA and 3-(4,5-Dimethylthiazol-2-yl)-62 2,5-diphenyl-2H-tetrazolium bromide (MTT) were obtained from Sigma-Aldrich (St. Louis, MO, USA). RPMI-1640 medium and fetal bovine serum (FBS) were obtained from Gibco Life Technologies (Carlsbad, CA, USA). Monoclonal antibodies against p53 and bcl-2 (mouse anti-mouse) were obtained from Santa Cruz Biotechnology, Inc. (Dallas, TX, USA).

Cell culture. The Bel-7402 human hepatocellular carcinoma (HCC) cell line was obtained from the Cancer Research Institute of Sun Yat-sen University (Guangzhou, China). Bel-7402 cells were placed in RPMI-1640 medium supplemented with $10 \%$ FBS, $100 \mathrm{U} / \mathrm{ml}$ penicillin and $100 \mu \mathrm{g} / \mathrm{ml}$ streptomycin (Gibco Life Technologies) in a humidified atmosphere of $5 \% \mathrm{CO}_{2}$ and $95 \%$ air at $37^{\circ} \mathrm{C}$. The medium was replaced twice per week. Once cells became confluent, subculture was conducted using trypsinization. Cells at passage numbers 3-6 were used for subsequent experiments.

Cell proliferation assay and cell cycle assay. Human Bel-7402 hepatoma cells were counted and seeded into 96-well culture plates at a density of $2 \times 10^{4}$ cells/well. Following incubation with various concentrations of Cor- $\mathrm{Ru}$ (II) $(0,12.5,25,50$ and $100 \mu \mathrm{g} / \mathrm{ml}$ ) for $48 \mathrm{~h}$, each well was washed twice with phosphate-buffered saline (PBS) to remove any unabsorbed drugs. Cell proliferation was measured using an MTT assay. Briefly, $200 \mu \mathrm{l}$ of $0.5 \mathrm{mg} / \mathrm{ml}$ MTT in Dulbecco's modified Eagle's medium was added to each well and incubated for $6 \mathrm{~h}$. Formazan crystals were dissolved in $150 \mu \mathrm{l}$ DMSO (Jerry Biotechnology, Shanghai, China) and the absorbance was measured at a wavelength of $630 \mathrm{~nm}$ with an enzyme-linked immunosorbent assay reader (BioRad 3550; Bio-Rad Laboratories, Hercules, CA, USA). Cell cycle progression was assessed using a flow cytometer (FACS Calibur cytometer, BD Biosciences, Franklin Lakes, NJ, USA). Briefly, cells were

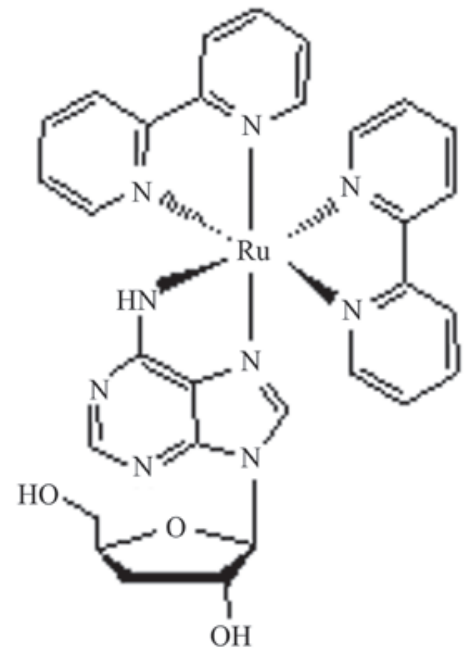

Figure 1. Molecular structure of the ruthenium(II) complex coordinated by cordycepin.

harvested, adjusted to a concentration of $10^{6}$ cells $/ \mathrm{ml}$ and were fixed with ice-cold $70 \%$ ethanol (16). Cells were washed with PBS, incubated with $0.1 \mathrm{mg} / \mathrm{ml}$ RNase (Sigma-Aldrich) at $37^{\circ} \mathrm{C}$ for $10 \mathrm{~min}$ and stained with $50 \mu \mathrm{g} / \mathrm{ml}$ of PI. Samples were analyzed by flow cytometry.

Cell morphology assay. Cells were counted and seeded into 96-well culture plates at a density of $2 \times 10^{4}$ cells/well. Following incubation with Cor-Ru(II) for 48 h, $75 \%$ ethanol (Shanghai Chemical Reagent Co., Ltd., Shanghai, China) was added to each well. and cells were washed twice with PBS to remove any unabsorbed drugs. Morphological changes were observed using a fluorescence microscope (DM6000B; Leica Microsystems GmbH, Wetzlar, Germany) and Hoechst 33258 (Beyotime Institute of Biotechnology, Shanghai, China) staining.

Cell apoptosis assay. Cells were counted and seeded into 6 -well culture plates at a density of $1 \times 10^{6}$ cells/well. Following incubation with drugs for $48 \mathrm{~h}$. Cell apoptosis was assessed by flow cytometry. Cells were harvested and washed twice with PBS at $4^{\circ} \mathrm{C}$, stained with $20 \mu \mathrm{l}$ Annexin $\mathrm{V}$ and $20 \mu \mathrm{l}$ propidium iodide (PI; Beyotime Institute of Biotechnology, Shanghai, China) for 10-15 min at room temperature. Samples were analyzed by flow cytometry (FACS Calibur cytometer; BD Biosciences).

Western blot analysis. Cells were harvested and lysed for $20 \mathrm{~min}$ in $200 \mu \mathrm{l}$ ice-cold lysis buffer $(50 \mathrm{mM}$ Tris- $\mathrm{HCl}$, $\mathrm{pH} 7.5 ; 250 \mathrm{mM} \mathrm{NaCl} ; 2 \mathrm{mM}$ ethylenediaminetetraacetic acid; $10 \%$ glycerol; $0.1 \%$ NP-40; $0.5 \mathrm{mM}$ phenylmethylsulfonyl fluoride; $10 \mu \mathrm{g} / \mathrm{ml}$ aprotinin; $10 \mu \mathrm{g} / \mathrm{ml}$ leupeptin; $1 \mathrm{mM} \mathrm{NaF}$; $0.1 \mathrm{mM} \mathrm{Na}_{3} \mathrm{VO}_{4}$; and $1 \mathrm{mM}$ dichlorodiphenyltrichloroethane). The supernatants were obtained by centrifugation at $13,400 \mathrm{xg}$ at $4^{\circ} \mathrm{C}$ for $3 \mathrm{~min}$. Protein content was assayed by the Bradford method (17). Protein (30 $\mu \mathrm{g})$ was loaded in each lane, resolved using SDS-PAGE gel electrophoresis and blotted onto a nitrocellulose membrane (Shanghai ExCell Biology, Shanghai, China). Blots were probed with specific antibodies against p53 or bcl-2, following which membranes were incubated with 
A

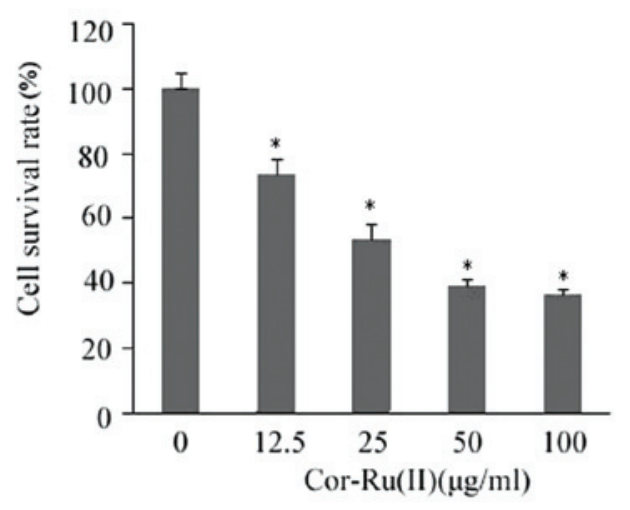

B

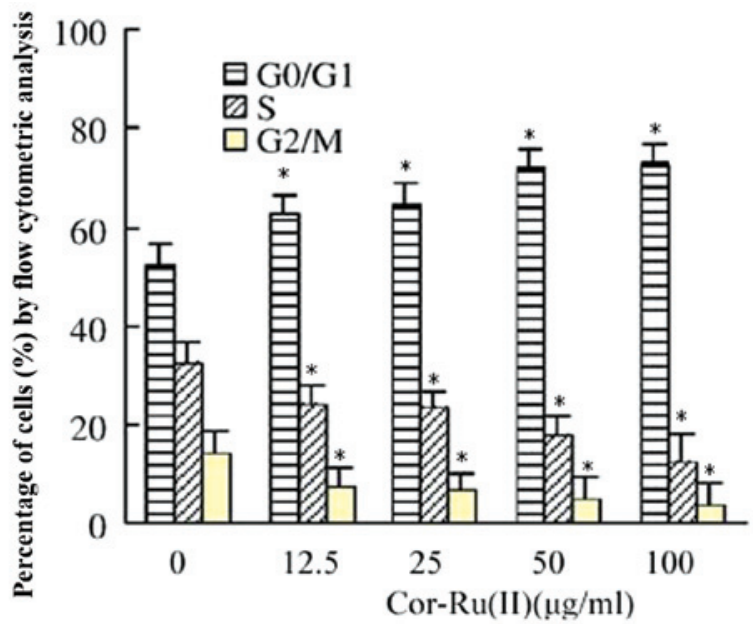

Figure 2. Effect of Cor-Ru(II) on Bel-7402 cell proliferation. (A) Arrested Bel-7402 cells were stimulated with $10 \%$ fetal bovine serum prior to treatment with varying concentrations of Cor-Ru(II) (0, 12.5, 25, 50 and $100 \mu \mathrm{g} / \mathrm{ml}$ ) over $48 \mathrm{~h}$. Bel-7402 cell proliferation was measured by an MTT assay. (B) Arrested Bel-7402 cells were stimulated with $10 \%$ fetal bovine serum prior to the addition of varying concentrations of Cor-Ru(II) $(0,12.5,25,50$ and $100 \mu \mathrm{g} / \mathrm{ml})$ over 48 h. Bel-7402 cells cycle progression was assayed by flow cytometry. Data represent the mean \pm standard deviation of five separate experiments. ${ }^{*} \mathrm{P}<0.05$, compared with cells treated with $0 \mu \mathrm{g} / \mathrm{ml}$ Cor-Ru(II). Ctrl, control cells (hepatoma cells treated with Dulbecco's modified Eagle's medium only). Cor-Ru(II), ruthenium(II) complex coordinated by cordycepin.

the rabbit anti-mouse peroxidase-conjugated second antibody (Santa Cruz Biotechnology, Inc.). Blots were treated with an enhanced chemiluminescence agent (Biorbyt, London, England) and exposed to CL-X films (Kodak, Rochester, NY, USA).

Ultraviolet $(U V)$-titration. UV visible absorption spectra were measured using a UV-2550 spectrophotometer (Unico Shanghai Instruments Co., Ltd., Shanghai, China). Equal quantities of buffer were added to the control and sample and cells were exposed to the Cor-Ru(II) complex. Calf thymus (CT)-DNA $(2 \mu \mathrm{l})$ solutions were added to the two samples and mixed. Complex-DNA solutions were incubated for $3 \mathrm{~min}$ prior to recording the absorption spectra. The ratio of DNA to Cor-Ru(II) complex was then increased until the absorption peak of the sample remained stable (18). The intrinsic binding constant, K, of ruthenium(II) complex to DNA was calculated from the following equation (19):

$$
\frac{[\mathrm{DNA}]}{\varepsilon_{\mathrm{a}}-\varepsilon_{\mathrm{f}}}=\frac{[\mathrm{DNA}]}{\varepsilon_{\mathrm{b}}-\varepsilon_{\mathrm{f}}}+\frac{1}{\mathrm{~K}_{\mathrm{b}}\left(\varepsilon_{\mathrm{b}}-\varepsilon_{\mathrm{f}}\right)}
$$

Where [DNA] is the concentration of CT-DNA (in bps), and the apparent absorption coefficients $\varepsilon_{\mathrm{a}}, \varepsilon_{\mathrm{f}}$ and $\varepsilon_{\mathrm{b}}$ correspond to $\mathrm{A} /[\mathrm{Ru}]$, the absorbance for the free ruthenium complex and the absorbance for the ruthenium complex in the fully bound form, respectively. $\mathrm{K}$ is the equilibrium binding constant in $\mathrm{M}^{-1}$.

Fluorescence quenching. Fluorescence quenching of EB-DNA complexes can be used to detect whether a compound has an affinity for DNA regardless of its binding mode. It measures the ability of compounds to moderate the EB fluorescence intensities in EB-DNA complex samples (20). The EB-DNA $(16 / 100 \mu \mathrm{M})$ solution was prepared and $3 \mathrm{ml}$ was transferred to a colorimetric cell (Yanhui Bio, Shanghai, China). Cor-Ru(II) complex $(2 \mu \mathrm{l} ; 1 \mathrm{mM})$ solution was added at 3-min intervals,

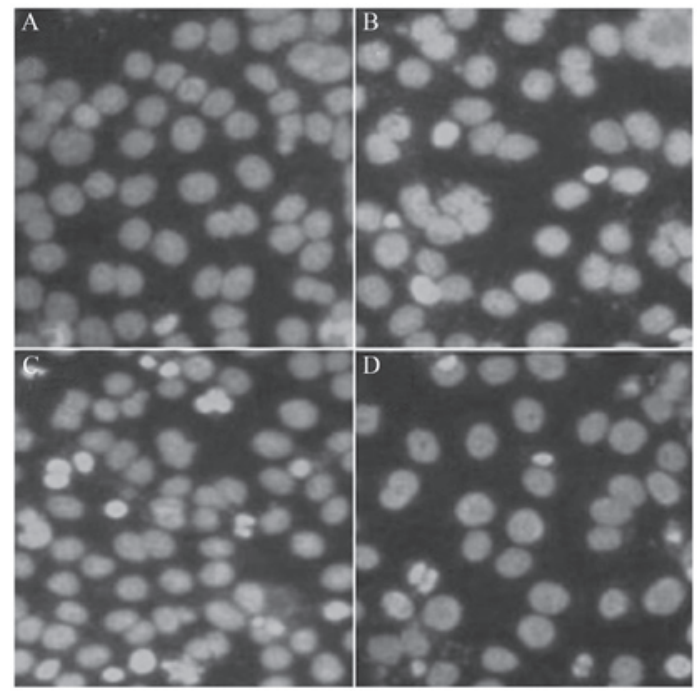

Figure 3. Effect of Cor-Ru(II) on Bel-7402 cell morphology (x200). Images show cells treated with (A) $0 \mu \mathrm{g} / \mathrm{ml}$ Cor-Ru(II); (B) $25 \mu \mathrm{g} / \mathrm{ml}$ Cor-Ru(II); (C) $50 \mu \mathrm{g} / \mathrm{ml}$ Cor-Ru(II); and (D) $100 \mu \mathrm{g} / \mathrm{ml}$ Cor-Ru(II). Arrested Bel-7402 cells were stimulated with $10 \%$ fetal bovine serum in the absence or presence of Cor-Ru(II) $(0,25,50$ and $100 \mu \mathrm{g} / \mathrm{ml})$ over $48 \mathrm{~h}$. Cells were monitored using a fluorescence microscope equipped with a camera. Each experiment was repeated three times. Cor-Ru(II), ruthenium(II) complex coordinated by cordypecin.

increasing the ratio of complex to DNA until the absorption peak of the sample remained unchanged.

Viscosity experiments. The viscosity test is an effective method to evaluate the interaction mode of compounds with DNA. Varying concentrations of a solution of Cor $\mathrm{Ru}(\mathrm{II})$ complex, [Ru(bpy)3] $\mathrm{Cl}_{2}$ and DNA in Tris- $\mathrm{HCl}$ buffer media were prepared: [2]/[DNA] $=0,0.02,0.04,0.06,0.08,0.1$. Prior to testing, these were maintained for $1 \mathrm{~h}$ at $30 \pm 0.1^{\circ} \mathrm{C}$ in a thermostatic water bath. The time that each concentration of solution took to pass through the capillary tube was then determined 

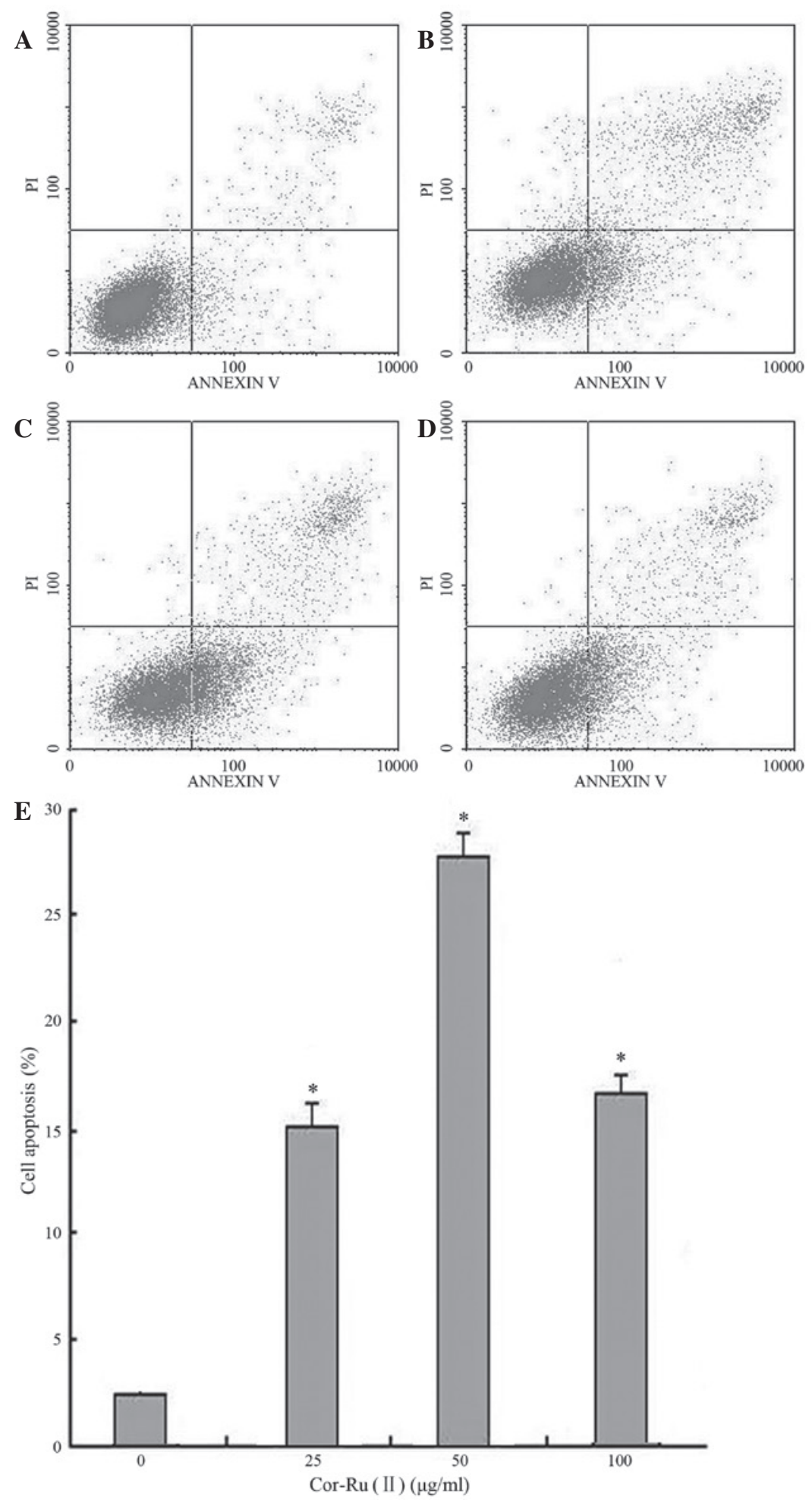

Figure 4. Effect of Cor-Ru(II) on the apoptotic rate of Bel-7402 cells. Cells were treated with (A) $0 \mu \mathrm{g} / \mathrm{ml} \mathrm{Cor-Ru(II);} \mathrm{(B)} 25 \mu \mathrm{g} / \mathrm{ml} \mathrm{Cor-Ru(II);} \mathrm{(C)} 50 \mu \mathrm{g} / \mathrm{ml}$ $\mathrm{Cor}-\mathrm{Ru}(\mathrm{II})$; and (D) $100 \mu \mathrm{g} / \mathrm{ml}$ Cor-Ru(II). Arrested Bel-7402 cells were stimulated with $10 \%$ fetal bovine serum prior to treatment with varying concentrations of $\mathrm{Cor}-\mathrm{Ru}(\mathrm{II})(0,25,50$ and $100 \mu \mathrm{g} / \mathrm{ml})$ over $48 \mathrm{~h}$. The apoptotic rate of Bel-7402 cells was assayed by flow cytometry (E). Data points are presented as the mean \pm standard deviation of three separate experiments. " $\mathrm{P}<0.05$, compared with cells treated with $0 \mu \mathrm{g} / \mathrm{ml} \mathrm{Cor}-\mathrm{Ru}$ (II). Cor-Ru(II), ruthenium(II) complex coordinated by cordycepin.

using an Ubbelohde viscometer (Shanghai Yishi Electronic Technology Co., Ltd., Shanghai, China). The formula by which viscosity was calculated was: $\eta=\left(\mathrm{t}-\mathrm{t}_{0}\right) / \mathrm{t}_{0}$. Where $\eta$ is the viscosity, $t$ is the flow time of solution and $t_{0}$ is the flow time of pure solvent. The viscosity can be calculated by the flow time of the solution and pure solvent in the capillary. Viscosity curves were obtained by plotting $\left(\eta / \eta_{0}\right)^{1 / 3}$ on the $y$-axis and $r(r=[2] /[D N A])$ on the $x$-axis.

Statistical analysis. Statistical analysis was conducted to compare three or more groups using one-way analysis of variance and Dunnett's test. The data represent the 


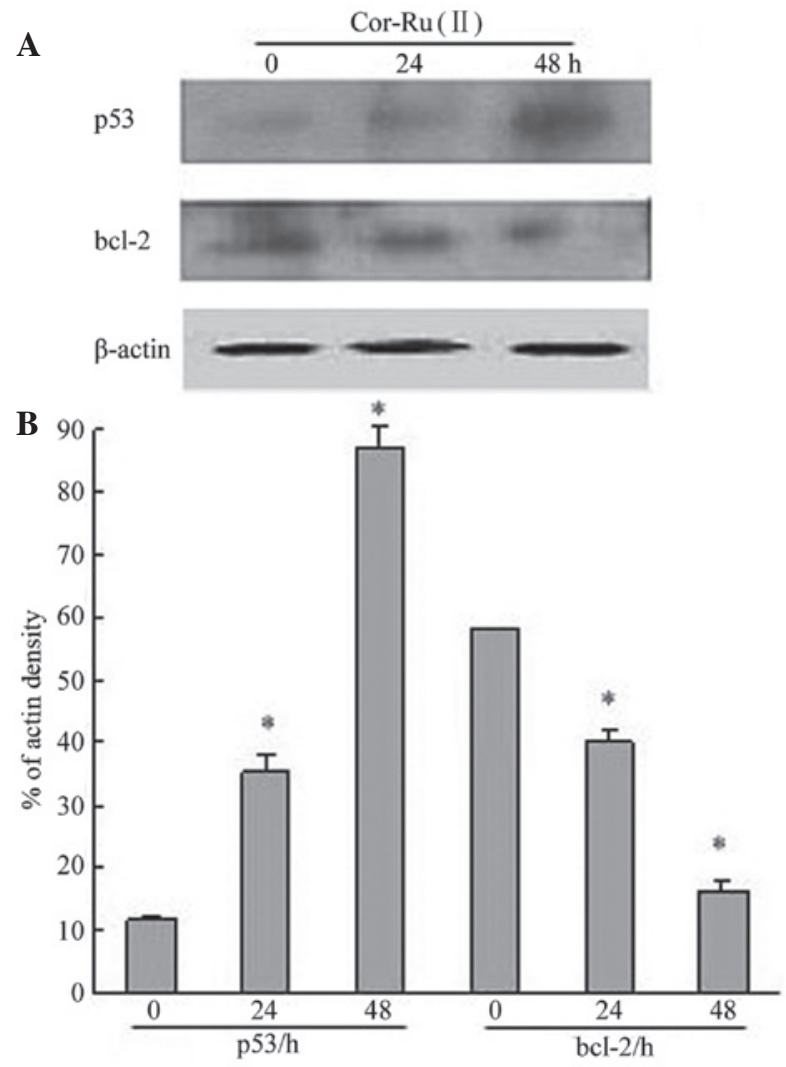

Figure 5. Effect of Cor-Ru(II) on the expression of p53 and bcl-2. Arrested Bel-7402 cells were treated with and without $50 \mu \mathrm{g} / \mathrm{ml} \mathrm{Cor-Ru(II)} \mathrm{for} 0,24$ or $48 \mathrm{~h}$ ). (A and B) Cell lysates were analyzed by western blot analysis with antibodies as indicated. Experiments were repeated three times. ${ }^{*} \mathrm{P}<0.05$, compared with untreated cells. Cor-Ru(II), ruthenium(II) complex coordinated by cordycepin.

means \pm standard deviation and $\mathrm{P}<0.05$ was considered to indicate a statistically significant difference. SAS System for Elementary Statistical Analysis was used for statistical analysis (SAS Institute Inc., Cary, NC, USA).

\section{Results}

Effect of Cor-Ru(II) on Bel-7402 cell proliferation. Bel-7402 cells were treated with various concentrations of $\mathrm{Cor}-\mathrm{Ru}(\mathrm{II})$ $(0,12.5,25,50,100 \mu \mathrm{g} / \mathrm{ml})$ for $48 \mathrm{~h}$, and cell proliferation was analyzed using an MTT assay. The results showed that Cor-Ru(II) significantly inhibited the proliferation of Bel-7402 cells induced by $10 \%$ FBS, in a dose-dependent manner (Fig. 2A). The rate of inhibition was $\sim 50 \%$ when Bel-7402 cells were treated with Cor-Ru(II) at a concentration of $25 \mu \mathrm{g} / \mathrm{ml}$. To further investigate the mechanisms by which Cor-Ru(II) suppresses cell proliferation, cell cycle progression in Bel-7402 cells treated with various concentrations of $\mathrm{Cor}-\mathrm{Ru}(\mathrm{II})$ was assayed by flow cytometry. The results showed that $\mathrm{Cor}-\mathrm{Ru}(\mathrm{II})$ significantly suppresses cell progression from G1 to S phase in a dose-dependent manner (Fig. 2B). These findings suggest that $\mathrm{Cor}-\mathrm{Ru}(\mathrm{II})$ inhibits cell proliferation via suppression of cell cycle progression.

Effect of Cor-Ru(II) on Bel-7402 cell morphology. Bel-7402 cells were treated with various concentrations of
A

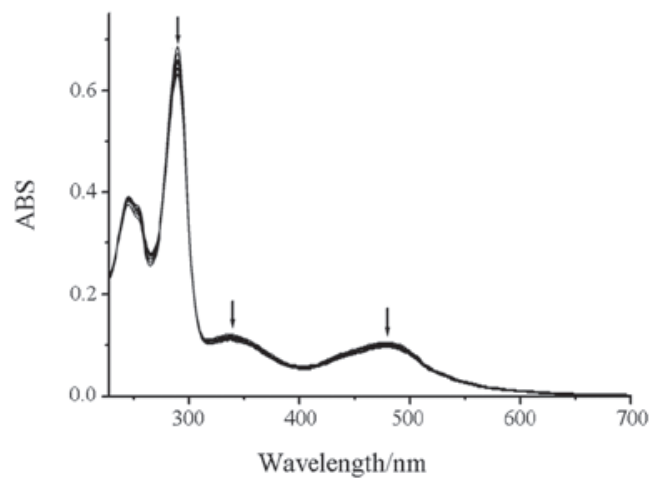

B

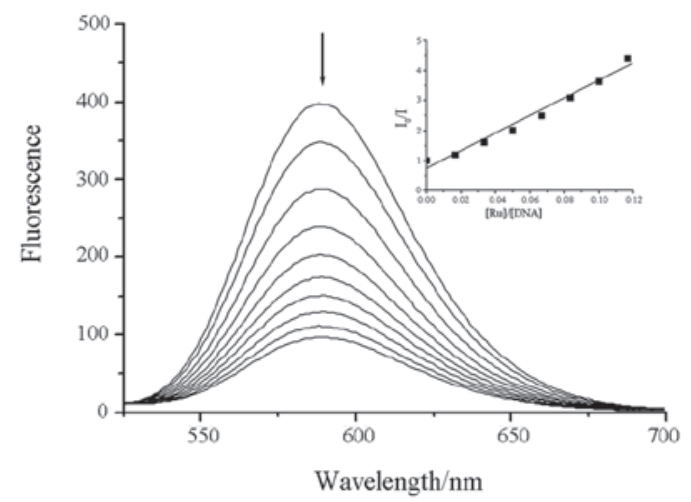

C

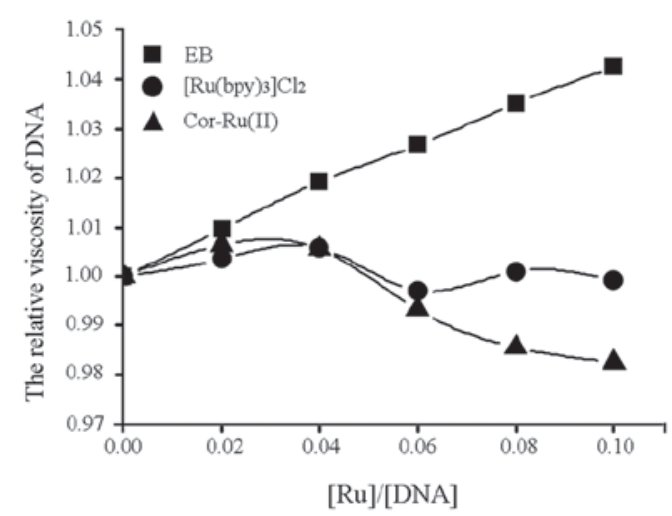

Figure 6. Interaction of Cor-Ru(II) with calf thymus DNA. (A) Electronic spectra of Cor-Ru(II) in the absence and in presence of calf thymus DNA. Cor-Ru(II) $=20 \mu \mathrm{M}$. (B) Steady emission spectra of EB-DNA in the absence and presence of Cor-Ru(II). [EB]=4 $\mu \mathrm{M}$; [DNA] $=8 \mu \mathrm{M}$; and $[\mathrm{Cor}-\mathrm{Ru}(\mathrm{II})]=1 \mathrm{mM}$. (C) Change in relative viscosity of calf thymus DNA in the absence and in presence of Cor-Ru(II). [DNA] $=0.5 \mathrm{mM}$. Cor-Ru(II), ruthenium(II) complex coordinated by cordycepin.

Cor-Ru(II) $(0,25,50,100 \mu \mathrm{g} / \mathrm{ml})$ for $48 \mathrm{~h}$, cells were stained with Hoechst 33258 and the morphology was observed using a fluorescence microscope (Fig. 3). The cells displayed several features consistent with apoptosis, such as cellular shrinkage, condensation and margination of the chromatin, and ruffling of the plasma membrane, which were not observed in the control group.

Effect of Cor-Ru(II) on Bel-7402 cell apoptosis. Bel-7402 cells were treated with various concentrations of $\mathrm{Cor}-\mathrm{Ru}(\mathrm{II})$ $(0,25,50$ and $100 \mu \mathrm{g} / \mathrm{ml})$ for $48 \mathrm{~h}$ and cell apoptosis rates were assessed by flow cytometry (Fig. 4). The results demonstrated 
that compared with the control group that was treated with DMEM only, Cor-Ru(II) significantly stimulated cell apoptosis. The percentage of apoptotic cells in samples treated with 0, 25, 50 and $100 \mu \mathrm{g} / \mathrm{ml}$ Cor-Ru(II) were 3.4, 15.7, 27.4 and $16.7 \%$ respectively.

Effect of Cor-Ru(II) on p53 and bcl-2 expression. To further investigate the mechanisms underlying the effect of Cor-Ru(II) on cell apoptosis, the expression of p53 and bcl-2 was measured by western blot analysis, using the appropriate antibodies. Arrested Bel-7402 cells were treated with $50 \mu \mathrm{g} / \mathrm{ml}$ Cor-Ru(II) for 0,24 and $48 \mathrm{~h}$. The results suggested that Cor-Ru(II) markedly stimulates the expression of the tumor suppressor factor, p53, but decreases the expression of the anti-apoptotic bcl-2 protein in a dose-dependent manner (Fig. 5). Therefore, Cor-Ru(II) stimulation of p53 and inhibition of bcl-2 may result in increased cell apoptosis and reduced cell proliferation.

DNA binding properties of Cor-Ru(II). Use of electron absorption spectra is the most common method to investigate the interaction of transition metal complexes with biological molecules. In general, when metal complexes bind to DNA bases by the classic intercalation mode, the electron absorption produces a hypochromic effect and a red-shift effect. The degree of the hypochromic effect is closely correlated with the affinity of the complex for the DNA molecule. The interaction of Cor-Ru(II) and CT-DNA is shown in Fig. 6.

The results showed that the electron absorption produced a marked hypochromic and red shift effect following addition of the CT-DNA solution to the Cor-Ru(II) complex solution (Fig. 6A). The metal to ligand charge transfer transition in the spectra of the Cor-Ru(II) complex appeared as a red-shift from 479 to $484 \mathrm{~nm}$, with hypochromism of $11.2 \%$. In addition, the intraligand pi-pi* transition absorption in the spectra of the Cor-Ru(II) complex appeared as a red-shift from 290 to $291 \mathrm{~nm}$, with hypochromism of $8.0 \%$ (21).

The Cor-Ru(II) complex emits a weak fluorescent signal in Tris- $\mathrm{HCl}$ buffer solution. Application of the fluorescence quenching of EB-DNA can be used to measure the affinity of the complex for DNA (Fig. 6B). There was a strong fluorescence emission from the EB-DNA solution in the range of 500-700 nm, with the highest peak of emission at $596 \mathrm{~nm}$, which was excited by $370 \mathrm{~nm}$ ultraviolet visible light. A marked reduction in the fluorescence intensity of the EB-DNA solution was observed following addition of Cor-Ru(II) or cordycepin. These results indicate that Cor-Ru(II) or cordycepin binds competitively with DNA to release EB from the DNA molecule, which results in a reduction of the fluorescence intensity of EB-DNA (22). According to the fluorescence intensity change of the solution with increasing concentrations of Cor-Ru(II), Kr was calculated using the Stem-Volmer equation: $\mathrm{I}_{0} / \mathrm{I}=1+\mathrm{Kr}$. The fluorescence intensity of the solution is inversely proportional to the concentration of the complex. $\mathrm{Kr}$ was calculated as $4.22( \pm 0.2) \times 10^{5}$ (Fig. $\left.6 \mathrm{~B}\right)$.

The binding mode of the complex with DNA was investigated using the viscosity test. In general, the double helix chain of DNA is long and the viscosity is greater when a complex binds with DNA in the intercalation mode. The results of the present study showed that the viscosity of DNA exhibited an irregular change when the Cor-Ru(II) complex bound with
DNA by the electrostatic mode, and that the viscosity of DNA reduced, as a result of the drape or inflection of the DNA double helix chain when the complex bound with DNA by the groove combined mode. The viscosity of DNA increased at a constant rate with increasing concentrations of EB (Fig. 6C). The viscosity of DNA exhibited an irregular change with increasing concentrations of $\left[\mathrm{Ru}(\mathrm{bpy})_{3}\right] \mathrm{Cl}_{2}$. However the viscosity of DNA decreased at a constant rate with increasing concentrations of Cor-Ru(II), indicating that the complex is likely to bind with DNA in the groove combined mode.

\section{Discussion}

HCC is a primary malignancy of the liver. Each year, more than half a million people worldwide are diagnosed with this disease. Liver cancer is the fifth most common type of cancer in males and the seventh most common in females (23). It has been shown that antineoplastic agents work by inhibiting cell proliferation and angiogenesis, amongst other things. The results of the present study showed that, Cor-Ru(II) significantly inhibited human Bel-7402 hepatoma cell proliferation and cell cycle progression.

Recent studies have demonstrated that certain small molecule drugs inhibit the growth of tumor cells by disrupting the synthesis of RNA and DNA (18). In the current study, Cor-Ru(II) was shown to bind to DNA by the groove binding mode $\left(\mathrm{K}_{\mathrm{b}}=4.22( \pm 0.2) \times 10^{5} \mathrm{M}^{-1}\right)$. It was also demonstrated that this complex interfered with the synthesis of DNA, thereby inhibiting the proliferation of Bel-7402 cells.

Apoptosis and cell proliferation are linked by cell-cycle regulators and apoptotic stimuli that affect each of these processes. Apoptosis is almost present in proliferation cells (24). The present study confirmed that Cor- $\mathrm{Ru}(\mathrm{II})$ induces cell apoptosis in Bel-7402 cells and certain mophological features of apoptosis, such as cellular shrinking, chromatin condensation and membrane blebbing were observed in these cells. p53 is one of the most commonly mutated tumor suppressors in human cancers and is involved in the cellular response to a broad array of stresses via regulation of apoptosis, cell cycle arrest, senescence, DNA repair and genetic stability. p53 participates directly in the intrinsic apoptosis pathway by interacting with the multidomain members of the Bcl-2 family in order to induce mitochondrial outer membrane permeability (25). The anti-apoptotic bcl-2 protein is a member of the Bcl-2 family, which is important in the regulation of apoptosis (26). The current data suggest that Cor- $\mathrm{Ru}(\mathrm{II})$ upregulates the expression of p53 and downregulates the expression of bcl-2, thereby inducing apoptosis in Bel-7402 cells. These results suggest that $\mathrm{Cor}-\mathrm{Ru}(\mathrm{II})$ may be of use as a chemotherapeutic agent in $\mathrm{HCC}$.

In conclusion, Cor-Ru(II) significantly inhibited proliferation in Bel-7402 human hepatoma cells. Cor-Ru(II) appears to interfere with DNA synthesis via its interaction with DNA by the groove surface combination mode. It led to the induction of apoptosis, at least in part, by upregulation of p53 expression and downregulation of bcl-2 expression. The present data suggest a possible molecular mechanism mediating the inhibitive effect of Cor-Ru(II) in human hepatoma cells. The results also provide further evidence that Cor-Ru(II) may be an effective agent in the treatment of cancer. 


\section{Acknowledgements}

This study was supported by the Technological Bureau of Guangdong (grant no. 2010B031600292) and Guangdong Pharmaceutical University (grant no. GYFYLH201313).

\section{References}

1. Xu L, Liu Y, Tan YH and Mei WJ: The synthesis of a novel ruthenium (II) complex with cordycepin and preliminary research of its killing action on rat liver cancer cells J Guangzhou Univ Trad Chin Med 25: 215-219, 2008 (In Chinese).

2. Mei WJ, Liu Y, Liu J, Li J, Zheng K and Ji L: Synthesis, characterization and DNA-binding properties of mixed porphyrin-polypyridyl ruthenium(II) complexes. Trans Met Chem 30: 82-88, 2005.

3. Mei WJ, Liu YJ, Wang N, Ma YZ, Wang H, Luo LQ and Huang SL: The photocleavage properties of a nove ruthenium(II) complex on liver cancer cells Bel-7402 DNA. Trans Met Chem 31: 1024-1027, 2006

4. Sava G, Zorzet S, Giraldi T, Mestroni G and Zassinovich G: Antineoplastic activity and toxicity of an organometallic complex of ruthenium(II) in comparison with cis-PDD in mice bearing solid malignant neoplasms. Eur J Cancer Clin Oncol 20: 841-847, 1984

5. Keppler BK, Henn M, Juhl UM, Berger MR, Niebl R and Wagner FE (eds): New ruthenium complexes for the treatment of cancer. In: Progress in Clinical Biochemistry and Medicine. Vol 10, Springer-Verlag Berlin Heidelberg, Germany, pp. 41-69, 1989.

6. Sava G, Bergamo A, Zorzet S, et al: Influence of chemical stability on the activity of the antimetastasis ruthenium compound NAMI-A. Eur J Cancer 38: 427-435, 2002.

7. Hotze AC, Velders AH, Ugozzoli F, et al: Synthesis, characterization, and crystal structure of alpha-[Ru(azpy)2(NO3)2] (azpy $=2-($ phenylazo $)$ pyridine $)$ and the products of its reactions with guanine derivatives. Inorg Chem 39: 3838-3844, 2000.

8. Zhang QL, Liu JG, Liu J, et al: DNA-binding and photocleavage studies of cobalt(III) mixed-polypyridyl complexes containing 2-(2-chloro-5-nitrophenyl)imidazo [4,5-f][1,10] phenanthroline. J Inorg Biochem 85: 291-296, 2001.

9. Zou XH, Ye BH, Li H, et al: The design of new molecular 'light switches' for DNA. J Biol Inorg Chem 6: 143-150, 2001.

10. Shu RH, Cai XD, Tan JP, Wei JY, Jiang Y and Wu FF: Effects of baicalin zinc complex on the immune responses in mice. Railway Med J 17: 321-323, 1989 (In Chinese).
11. Jiang Y: The observation of influence of baicalin Zinc complex in guinea pigs sensibilized on releasing SRS-A from its isolated lung. Railway Med J 15: 290-292, 1987 (In Chinese).

12. Chen ZF, Zhang M, Shi SM, et al: Synthesis, crystal structure and antibacterial activity of 2-aminobenzothiazole silver(I) nitrate. Chin J Appl Chem 22: 730-733, 2005 (In Chinese).

13. Yoshida J, Takamura S, Yamaguchi N, et al: Antitumor activity of an extract of Cordyceps sinensis (Berk.) Sacc. against murine tumor cell lines. Jpn J Exp Med 59: 157-161, 1989.

14. Thomadaki H, Scorilas A, Tsiapalis CM and Havredaki M: The role of cordycepin in cancer treatment via induction or inhibition of apoptosis: implication of polyadenylation in a cell type specific manner. Cancer Chemother Pharmacol 61: 251-265, 2008.

15. Kodama EN, McCaffrey RP, Yusa K and Mitsuya $H$ : Antileukemic activity and mechanism of action of cordycepin against terminal deoxynucleotidal transferase-positive (TdT+) leukemic cells. Biochem Pharmacol 59: 273-281, 2000.

16. Lu Q, Qiu TQ and Yang H: Ligustilide inhibits vascular smooth muscle cells proliferation. Eur J Pharmacol 542: 136-140, 2006.

17. Ku HK, Lim HM, Oh KH, Yang HJ, Jeong JS and Kim SK Interpretation of protein quantitation using the Bradford assay: comparison with two calculation models. Anal Biochem 434: 178-180, 2013.

18. Maheswafi PU and Palaniandavar M: DNA binding and cleavage activity $\mathrm{Ru}(\mathrm{Nti3}) 4$ (di-imine) $\mathrm{C} 12$ complexes. Inorg Chim Acta 357: 901-912, 2004.

19. Hartshorn RM and Barton JK: Novel dipyfidophenazine complexes of ruthenium(II): exploring luminescent reporters of DNA. J Am Chem Soc 114: 5919-5925, 1992.

20. Neyhart GA, Grover N, Smith SR, et al: Binding and kinetics studies of oxidation of DNA by oxoruthenium(IV). J Am Chem Soc 115: 4423-4428, 1993.

21. Nakabayashi $\mathrm{Y}$, Iwamoto $\mathrm{N}$, Inada $\mathrm{H}$ and Yamauchi $\mathrm{O}$ DNA-binding properties of flexible diamine bridged dinuclear ruthenium(II)-2,2'-bipyridine complexes. Inorg $\mathrm{Chem}$ Commun 9: 1033-1036, 2006.

22. Hong J, Yang GS, Duan CY, Guo ZJ and Zhu LG: Fluorescence quenching of EB-DNA complex by a novel di-bipyridyl ruthenium(II) complex of p-tert-butyltetrathiacalix[4]arene. Inorg Chem Commun 8: 988-991, 2005.

23. El-Serag HB: Hepatocellular carcinoma. N Eng J Med 365: 1118-1127, 2011.

24. Alenzi FQ: Links between apoptosis, proliferation and the cell cycle. Br J Biomed Sci 61: 99-102, 2004.

25. Vaseva AV and Moll UM: The mitochondrial p53 pathway. Biochim Biophys Acta 1787: 414-420, 2009.

26. Korsmeyer SJ, Shutter JR, Veis DJ, Merry DE and Oltvai ZN: Bcl-2/Bax: a rheostat that regulates an anti-oxidant pathway and cell death. Semin Cancer Biol 4: 327-332, 1993. 